\title{
CONCLUSÕES E RECOMENDAÇÕES DO II ENCONTRO NACIONAL DE TRADUTORES ${ }^{1}$
}

\section{CONCLUSÕES}

A principal conclusão tirada dos diversos painéis e palestras apresentados diz respeito à importância do papel do tradutor no cenário nacional.

As editoras vêm conhecendo um progresso significativo, com a ampliação dos títulos publicados, a reedição de obras bem sucedidas comercialmente e o interesse demonstrado pelo público, graças em grande parte à qualidade das traduções das obras estrangeiras. Do mesmo modo, as empresas usuárias de tradução a testam sua dependência cada vez maior deste tipo de serviço, devido a contratos firmados com empresas estrangeiras e à importação e intercâmbio de tecnologia.

Tais fatos são decorrentes da necessidade de integração do país no contexto universal da ciência e da cultura, processo onde o tradutor tem uma função insubstituível.

Apesar desta importância constatada e reiteradamente enfatizada em todos os pronunciamentos e debates, vários pontos negativos foram destacados como obstáculo ao bom desempenho profissional do tradutor:

- A baixa remuneração dos tradutores de livros, manuais e artigos técnicos ou daqueles lotados em empresas.

- O prazo excessivamente limitado exigido pela maioria dos usuários de tradução, o que restringe o tempo dedicado à pesquisa e revisão imprescindíveis à boa qualidade do trabalho traduzido.

- A quase inexistência de contratos entre tradutores e editoras, delimitando os direitos e deveres de cada um.

- A improvisação de profissionais, a subcontratação e contratação de pessoas não qualificadas para o exercício desta profissão, o que revela o pouco caso com que ela é vista pelas editoras, empresas e sociedade em geral.

\footnotetext{
${ }^{1}$ N.E.: O II Encontro Nacional de Tradutores foi realizado nos dias 29 a 31 de maio de 1985 na PUC-Rio, sob a coordenação de Maria Candida Diaz Bordenave.
} 
- O não reconhecimento do alto nível de ensino existente nas escolas de tradução. Apesar de formar profissionais competentes e de desenvolver pesquisas na área de tradução, as escolas ainda não receberam, por parte das empresas e associações, o reconhecimento devido.

- A falta de união da classe, cujos membros, pela própria natureza de sua atividade, trabalham solitariamente, e, pelo volume de laudas que são obrigados a produzir diante da baixa remuneração, raramente encontram tempo disponível para participar de reuniões da categoria.

\section{RECOMENDAÇÕES}

1. Unificar os esforços dos órgãos representativos no sentido do reconhecimento da profissão e da regulamentação da categoria. A regulamentação possibilitaria o estabelecimento de um piso salarial para os tradutores contratados por firmas, e um preço mínimo por lauda para os autônomos.

2. Exigir a revisão da Lei 5.988, do Direito Autoral, para melhor assegurar a posição do tradutor como titular dos direitos autorais de seu trabalho, mesmo feito sob encomenda, com a revogação do Artigo 52, que permite a cessão da tradução em caráter definitivo. Por esta lei, revogado o artigo 52, os tradutores terão participação nas reedições, equiparando-se, assim, aos escritores, como coautores da obra traduzida.

3. Reivindicar a indicação do nome do tradutor na capa do livro e na ficha bibliográfica do mesmo, bem como a entrega ao tradutor de mais de um exemplar traduzido - ou um mínimo a ser estipulado.

4. Adotar um contrato padrão de tradução, a fim de proteger juridicamente os direitos dos tradutores. Reivindicar, para os contratos dos autônomos, que haja um prazo estipulado para o pagamento dos contratantes, e que este seja feito em ORTNs, devido à inflação. Reivindicar igualmente um adiantamento dos honorários no caso de obras muito extensas. 
5. Exigir a aprovação, por parte do tradutor, das modificações realizadas pelos revisores das editoras, para que não haja desrespeito ao seu texto, isto é, para que neles não sejam introduzidas notificações à sua revelia.

6. Juntar os esforços para que mais glossários sejam compilados, procurando sempre uma uniformização da terminologia técnica, que dever ser em língua portuguesa. Tal uniformização deve ria ficar a cargo de uma instituição, acadêmica ou não, a ser criada.

7. Requerer das empresas e firmas usuárias de tradução a possibilidade de estágios para tradutores e estudantes de tradução, possibilitando-lhes uma especialização que em muito contribuirá para a exatidão dos textos técnicos.

8. Insistir junto s colunas de livros nos jornais que mencionem, ao lado das informações sobre o livro, o nome do tradutor e uma apreciação ao seu trabalho.

9. Empenhar-se na regularidade de uma publicação especializada que referencie temas, obras novas e reivindicações pertinentes à profissão. 